\title{
Shallow intraplate seismicity in the Buenos Aires province (Argentina) and surrounding areas: is it related to the Quilmes Trough?
}

\author{
Eduardo Antonio Rossello ${ }^{1 *}$; Benjamín Heit ${ }^{2}$; Marcelo Bianchi ${ }^{3}$
}

doi: https://doi.org/10.18273/revbol.v42n2-2020002 @c) (i)

How to cite: Rossello, E.A.; Heit, B.; Bianchi, M. (2020). Shallow intraplate seismicity in the Buenos Aires province (Argentina) and surrounding areas: is it related to the Quilmes Trough?. Boletín de Geología, 42(2), 31-48. doi: 10.18273/revbol.v42n2-2020002.

\begin{abstract}
In the light of the November $30^{\text {th }}, 2018$ (N30) earthquake activity, some neighborhoods of the city of Buenos Aires were shaken by a $3.8 \mathrm{mb}$ earthquake (4.53 km estimated depth). We examined the historical and recent seismic records in order to analyze possible mechanisms related to the distribution of tectonic stresses as responsible for such unusual earthquakes in a region where only very little seismic activity is reported. According to this, at list one historical event occurred on June $5^{\text {th }}$, 1888 and other small magnitude earthquakes are mentioned since 1848 interpreted as being associated with the Rio de la Plata faulting. But there is, still no consensus about the role of this structure compared to other structures with orientation SW-NE. The lack of evidence to support one over the other structures makes it difficult to analyze these earthquakes. The presence of the Quilmes Trough connecting the Santa Lucía Basin in Uruguay and the Salado Basin in Argentina was recently proposed to play a tectonic role by a system of ENE-WSW trending controlled by extensional faulting related to the beginning of the Gondwana breakup. This depocenter with a thickness of almost 2,000 m of Mesozoic and Tertiary sequences could be acting as a zone of weakness in the crust and therefore responsible for the mentioned earthquake activity. The orientation of this structure correlates well with the present convergence vector between the Nazca and the South American plates and could therefore be propitious for strain release triggering shallow intraplate seismicity. We propose that most of the epicenters from historical and recent earthquakes might be aligned sub-parallel to the principal axis of the Quilmes Trough. Nevertheless, more data is needed to produce a reliable earthquake monitoring system in order to elucidate the tectonic stress regime and the existence of such structures at depth.
\end{abstract}

Keywords: Intraplate seismicity; Quilmes Trough; Rio de la Plata; Argentina; Uruguay.

\section{Sismicidad somera de intraplaca en la provincia de Buenos Aires (Argentina) y áreas adyacentes: ¿están relacionadas con la Fosa de Quilmes?}

\section{Resumen}

A partir de la actividad sísmica del 30 de noviembre de 2018 (N30), las cercanías de la ciudad de Buenos Aires fueron sacudidas por un terremoto de $3,8 \mathrm{mb}$ (4,53 $\mathrm{km}$ de profundidad estimada). Los registros sísmicos históricos y recientes fueron analizados para identificar rasgos tectónicos responsables inusuales en una región donde se informa muy poca actividad sísmica. Según registros históricos, un evento anterior ocurrió el 5 de junio de 1888 y otros de pequeña magnitud también se mencionan en la región desde 1848. Todos fueron interpretados como asociados con actividad tectónica a lo largo de la falla del Rio de la Plata. Pero, todavía no hay consenso sobre el papel de esta estructura en comparación con otras orientadas SWNE. Recientemente, se propuso la presencia de la Fosa de Quilmes (que conecta la cuenca de Santa Lucía en Uruguay y la cuenca del Salado en Argentina) controlado por fallas extensionales ENE-WSW, relacionadas con el comienzo de la ruptura de Gondwana. Este depocentro (con casi $2.000 \mathrm{~m}$ de secuencias mesozoicas y terciarias) actuaría como una zona de debilidad en la corteza y, por lo tanto, responsable de la actividad sísmica detectada. Su orientación se correlaciona bien con el vector de convergencia actual entre las placas de Nazca y Sudamérica y, por lo tanto, podría ser propicia para la liberación de tensión desencadenante de una sismicidad de intraplaca poco profunda. Proponemos que los epicentros recientes y la mayoría de los terremotos históricos podrían estar alineados con el eje principal de la Fosa de Quilmes. Sin embargo, se necesitan más datos para producir un sistema confiable de monitoreo de terremotos en esta región con el fin de mejorar la integridad de los catálogos de terremotos que podrían ayudar a dilucidar el régimen de tensión tectónica y la existencia de tales estructuras en profundidad.

Palabras clave: Sismicidad intraplaca; Fosa de Quilmes; Rio de la Plata; Argentina; Uruguay.

${ }^{1}$ Consejo Nacional de Investigaciones Científicas y Técnicas - Instituto de Geología y Ciencias Básicas de Buenos Aires, Facultad de Ciencias Exactas y Naturales, Universidad de Buenos Aires, Buenos Aires, Argentina. (*) ea_rossello@yahoo.com.ar ${ }^{2}$ GFZ German Research Centre for Geosciences. Albert-Einstein-Straße 42-46. Telegrafenberg, D-14473 Potsdam, Germany. heit@gfz-potsdam.de

${ }^{3}$ Instituto de Astronomia, Geofísica e Ciências Atmosféricas, Universidade de São Paulo, Rua do Matão, São Paulo, Brazil. m.tchelo@gmail.com 


\section{Introduction}

The Rio de la Plata River and the Buenos Aires province in particular, have always been considered to be of low earthquake risk (e.g. INPRES, 2019). Although there are some historical records showing that sparse earthquake activity has been documented since 1848. The sparse seismic activity in the region has always been described as related to a fault system along the Rio de la Plata River but geological and geophysical evidence supporting this assumption are still missing (Benavídez-Sosa, 1998).

The earthquake recorded near the city of Buenos Aires on November 30 2018 (N30), reawakened the discussion about the true character of the seismicity in this region as it is located far away from the traditional earthquake prone areas in the north and in the west of the country in Argentina. Although there are few reliable geophysical earthquake data, it is necessary to take this low seismicity into account and study the possible reasons for its occurrence. In the light of a possible nuclear power plant construction in the region, and considering that there might be other sources of man-made induced seismicity like deep injection wells, oil production wells and/or exploratory wells that could be responsible for earthquake activity, it is imperative to classify and quantify the real effects of tectonic activity and try to improve the location of earthquakes in this area.

In this work, we present a review of the different records from seismic events that occurred in the Rio de la Plata region and the Buenos Aires province in particular. We also present a model with our preferred interpretation suggesting that earthquake activity in this region might be related to the reactivation of the extensional faulting of the Quilmes Trough (QT) mainly because the location of most of the earthquakes is almost parallel to the QT basin axis. This idea is in disagreement with the proposed focal mechanism solution of the earthquake obtained by Venerdini et al. (2019) as they argue that the focal mechanism of the N30 earthquake supports a preferred WNW or NW-SE direction for the rupture. Unfortunately, due to a lack of strong earthquake activity and a well-established network of seismometers in the area, other studies failed to obtain focal mechanism solutions that could provide clear results about the distribution of stresses related to local faulting.

\section{Historical earthquakes}

Historical earthquakes can provide a good reference frame about the stress situation in a region. Small earthquakes have been reported in the Rio de la Plata since 1848 along with some strong earthquakes in the nearby regions (overview map Figure 1).

\section{The 1848 earthquake}

The first historical earthquake occurred on August $9^{\text {th }}, 1848$ at 18:35 with an approximate duration of 5 seconds and a MM V-VI (modified Mercalli) intensity between moderate and strong. According to reports, it was followed by aftershocks that lasted for more than one month until September $11^{\text {th }}, 1848$. At that time, the epicenter was assumed to be located in the Punta del Este Basin in Uruguay (Sánchez-Bettucci et al., 2016).

Two newspapers edited in Montevideo, The Defender of American Independence and El Comercio del Plata, offered extensive information about the earthquake pointing out that the seismic waves were felt strongest in the southeast and the reports reached as far as of 150 $\mathrm{km}$ towards the interior of the country (i.e. Uruguay). It was also felt in the Barrancas de San Gregorio area, located at approximately $60 \mathrm{~km}$, West of Montevideo, along the coast of the Rio de la Plata. A series of earthquakes were felt after the main shock with reports indicating that on the morning of August $15^{\text {th }}, 1848$ at 08:22 an earthquake was felt with a duration of 4 seconds; the second and third on the night of August 17-18 (one at 23:45 with a duration of about 8 seconds and the other, at 00:20 with a duration of 2 or 3 seconds). A fourth earthquake occurred on the night of September $11^{\text {th }}, 1848$ at 20:00, with an estimated duration of 14 to 16 seconds (Sánchez-Bettucci et al., 2016, from old Montevideo’s newspapers).

\section{The 1888 earthquake}

The most important historic earthquake in the Rio de la Plata region occurred on June $5^{\text {th }}, 1888$ at 00:20 local time, with the epicenter located $15 \mathrm{~km}$ south of Colonia and $41 \mathrm{~km}$ east of Buenos Aires ( $34^{\circ} 36^{\prime} \mathrm{S}, 57^{\circ} 53^{\prime} \mathrm{W}$ ). This earthquake was probably the strongest seismic event recorded in the region (Nature, 1884; Navarro, 2012). It was felt in the cities of Buenos Aires, La Plata and other small towns and villages along the Rio de Plata coastal regions (Sánchez-Bettucci et al., 2018a, from old Montevideo's newspapers). The magnitude is presumed to have been higher than 5.0 and was felt among the population in the region. There are extensive reports of the phenomenon in the press at that time that informs that the tremor was felt in localities as far as $400 \mathrm{~km}$ away from the epicenter. In Montevideo, the first pulse of the earthquake was not so strong, then there was a rest and then a second strong pulse arrived 
that lasted about 58 seconds. In the port of Montevideo, newspaper reports indicate that the waters suffered a violent change in depth becoming suddenly shallow. By the information received through telegraphic communications it was possible to establish that the town of Zárate, located on the north coast of Buenos Aires, was the northernmost point where the earthquake was felt. To the south, it was felt in La Plata but not perceived along the coastline until Bahía Blanca. This information has been used for a preliminary plot of what we would now call a shake map (see BenavídezSosa, 1998). The total duration of the shaking was estimated between 45 and 58 seconds divided as follows: a very weak first oscillatory movement that lasted approximately five seconds; a quiet time of three seconds; a second moderate movement with duration of 25 seconds, followed by a strong movement for 15 seconds (Benavídez-Sosa, 1998).

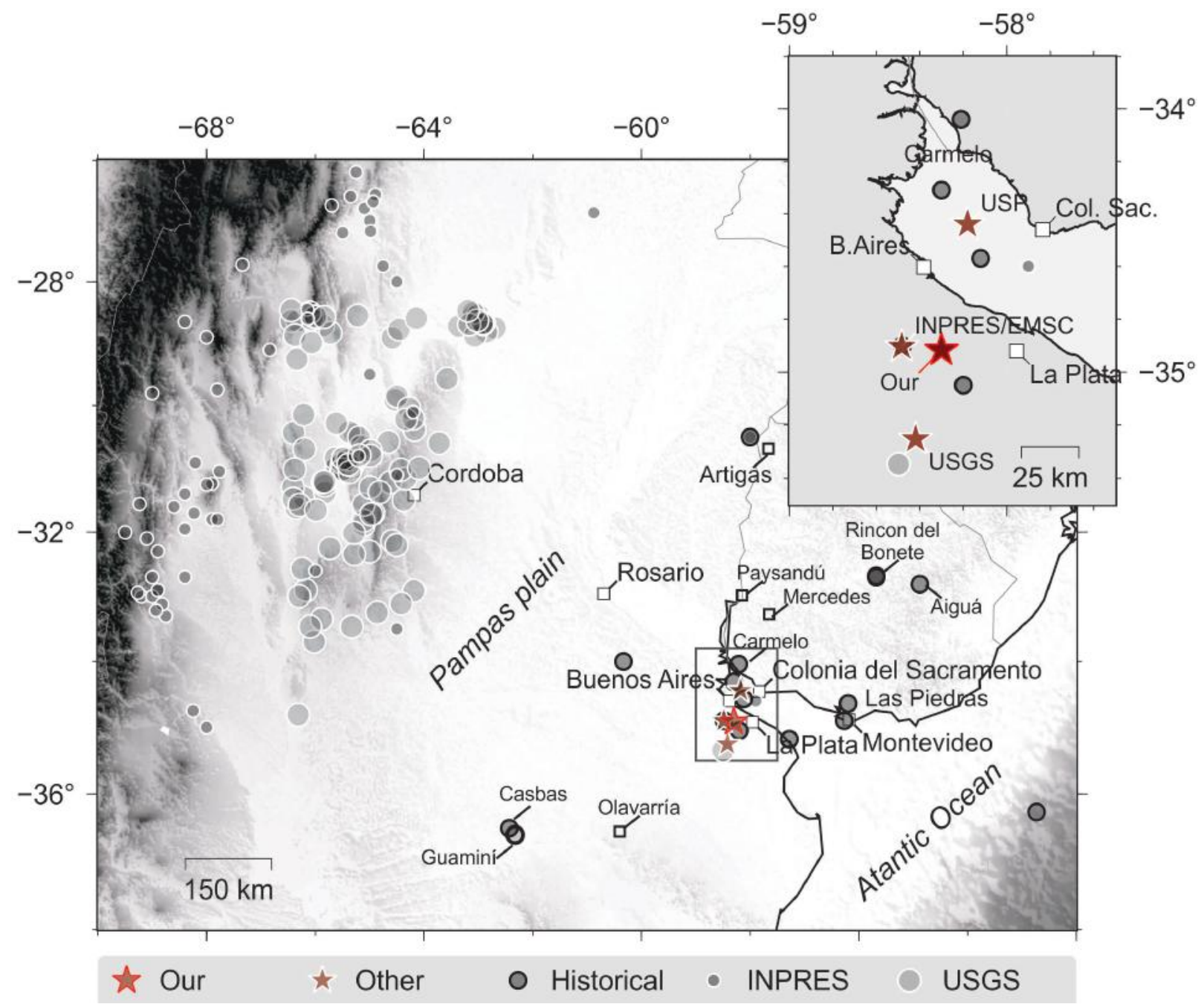

Figure 1. Distribution of earthquakes according to the different sources (USGS catalog since 1900, INPRES since 1692) and historical (different sources) in the Rio de la Plata region between the Buenos Aires Province (Argentina) and Uruguay and offshore. Col. Sac.: Colonia del Sacramento. 
For the latter, it is written in the newspaper "Tribuna Popular" that in Buenos Aires "the wood of the houses creaked loudly, the lamps of the houses wobbled, the furniture moved from its place and the hanging pictures fell from the walls; in some houses the objects of glassware and porcelain were broken, falling from the sideboards". The population was alarmed, saying that "the inhabitants of Buenos Aires have remained awake part of the night, overwhelmed by the strong earthquake. Also, in Colonia (Uruguay) the population felt a strong shaking, without injured or fatalities being declared. Glass and tiles from some trading houses were destroyed. In the Estanzuela, a place near the city of Colonia, part of a small house with a weak foundation on a sandy soil collapsed" (these data have been extracted by Sánchez-Bettucci et al. (2016) mainly from the newspaper La Tribuna Popular, published in Montevideo, in its editions of June $5^{\text {th }}$, 1888 and following days). The shaking was also felt in the Uruguayan cities of Mercedes, Paysandú and Artigas, located approximately in the same region of the epicenter of the earthquake, as well as in several cities and towns west of Buenos Aires. In summary, the earthquake of 1888 was felt in the cities of Colonia and Buenos Aires and also reported in a very large area that includes several Argentine provinces located nearby and almost the entire Uruguayan territory.

About the mechanism, there is a report about a possible "tsunamigenic phenomenon" that is described in the newspaper "The Municipality" from Rosario, as of June $26^{\text {th }} 1888$, which transcribes telegrams from Montevideo: "Last night at 00:20, there was a strong tremor, and during the whole cold morning many groups wandered along the streets fearing there would be more aftershocks. There was a first shock not so strong, then a rest and then a second and strong shock that lasted 58 seconds". In the following days the reports indicate that the earthquake was felt in Buenos Aires with walls collapses as in the case of the church of La Piedad that was under construction, as well as in some buildings in La Plata. Although, the worst part was reported in Uruguay in the towns of Punta del Este and Maldonado as the earthquake produced a tsunami that hit both coasts of Buenos Aires and Uruguay without causing any fatalities (Benavídez-Sosa, 1998). The newspaper "La Lucha de Colonia" (in SánchezBettucci et al., 2016) reported that "The Saturn steamboat that connected the ports of Buenos Aires and Colonia sailed through the center of the channel with more than 20 feet of depth when suddenly it stopped as if it touched the bottom. The captain had the probe thrown but he found that the ship, moved by a hidden force, sailed by itself from the gap and continued on its way. And in La Estanzuela, near Colonia, a part of a house collapsed". These reports might be reflecting changes in water level produced by the seismic waves passing through the river that could indeed represent waves generated by a landslide in the river terraces. Take notice that we have no information about the ships keel, but the reports point that the ship was a small steam boat and that the water depth was 20 feet, along the channel, thus as a speculative interpretation, we consider a possible water level change of at least 1 meter.

\section{Evidence of small magnitude earthquakes between 1933 and 2016 in the Buenos Aires Province}

Jaschek (1972) mentions a series of small magnitude earthquakes in the province of Buenos Aires, which unfortunately could not be recorded by seismographs due to the poor detection quality of the only equipment available at that time. The observatory of La Plata University (UNLP) had until 1950, only mechanical seismographs with scant amplification (about 175 times) that was not able to record local and weak seismicity. Later, instruments of greater sensitivity were acquired, although due to their constructive characteristics they were not fully adapted to record nearby earthquakes (Jaschek, 1972). According to this author, from all the earthquakes detected using this equipment during this period, there are some markings on the records indicating weak signals on the strips of the old mechanical seismograph but they are usually very difficult to identify as earthquakes. In the case, if it is identified as an earthquake, it is almost impossible to determine neither the distance nor the duration and intensity of the phenomenon on this kind of records. These markings just indicate the time the population of the affected areas felt underground noises, oscillations of the floor and walls, etc. Therefore, these markings just indicate that the technician had tried to identify some signals in the seismograph rolls that could be linked to the reports in the media. But clear evidence of the occurrence of earthquakes was still missing.

The detection and recording improved markedly when the earthquake of November $2^{\text {nd }}, 1971$, occurred (Jaschek, 1972). This earthquake showed that such events could be recorded by the equipment available in a way that allowed identifying the signal and assuring that the phenomena felt by the population was without any doubt an earthquake (Figure 2). This earthquake was strong enough to produce alarm in the towns of 
Álvarez Jonte, Vieytes and Magdalena (near La Plata, Figure 1) where some residents "heard noises on the roof as if rubble was falling and the wine bottles clinked on the shelves" and it would have had an intensity of four on the Modified Mercalli scale (Jaschek, 1972). According to the data recorded by the seismometer of the UNLP, its epicenter was determined $57 \mathrm{~km}$ southeast of La Plata (Jaschek et al., 1982).

On August $10^{\text {th }}, 2016$ at 21:01 local time, residents of Guaminí in the west of the Buenos Aires province perceived an earthquake (Figure 1). The National Institute of Seismic Prevention in Argentina (INPRES) published on its website the details of the earthquake in red, which means that it was "felt" by the population. The earthquake had a magnitude of $3.7 \mathrm{mb}$ and an estimated depth of 32 kilometers. The intensity, in the Modified Mercalli scale (Richter, 1958; Shearer, 2009; Stein and Wysession, 2009), was from II to III ("very weak to weak") in the towns of Casbas and Laguna Alsina (near the town of Guaminí, Figure 1). It was "felt slightly by some people at rest or in buildings" and that it did not cause any damages to the infrastructure (INPRES report).

On November $7^{\text {th }}, 2016$ at 04:47:50 local time, an earthquake occurred $420 \mathrm{~km} \mathrm{SW}$ of the Buenos Aires city in the area of Olavarría (Figure 1) with an estimated magnitude of $4 \mathrm{ML}$ and location $36.608^{\circ} \mathrm{S}$ and $62.327^{\circ} \mathrm{W}$ with a depth between $10 \mathrm{~km}$ and 14.6 $\mathrm{km}$ (INPRES report).

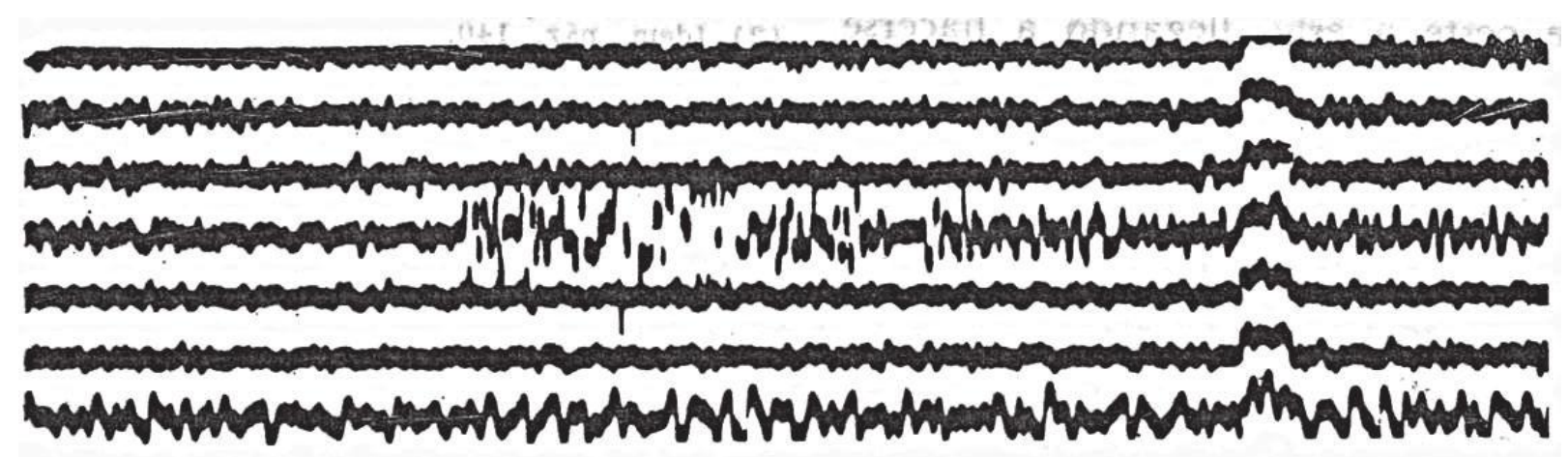

Figure 2. Historic record of the 1971 earthquake recorded by the Observatorio de la Plata by one short-period seismometer. The recording shows an upwards jump in the waveform on the $4^{\text {th }}$ time line. Scale is 1:1.9 in the vertical and 1: $1.9 \mathrm{~mm}$ in the horizontal (Jaschek, 1972).

Other earthquakes have been recently published by the "Protocolo Interinstitucional de Gestión de Información etapa: Preparación para la emergencia de sismos en el Territorio Argentino" with the participation of INPRES. This protocol contains some earthquakes in the Buenos Aires province in 1845 and 1967, but they do not appear on any other official reports.

\section{Summary of Uruguayan earthquakes}

A complete summary of earthquakes in Uruguay (Sánchez-Bettucci et al., 2018a, 2018b) can also be found in the historical earthquake report from the OGU (2019). This report accounts a number of earthquakes and tsunamis along the river in front of the city of Buenos Aires. Here we highlight some of the earthquakes that occurred in Uruguay and were also felt in Buenos Aires.
On June $26^{\text {th }}, 1988$ at $03: 24: 22$ (GMT) a $5.1 \mathrm{Mb}$ earthquake occurred in front of the coast of Uruguay (ca. $350 \mathrm{~km}$ from the city of Punta del Este) which was felt by the population along the Atlantic coast including the cities of Buenos Aires and Montevideo (Assumpção, 1998). Although the event had its epicenter on the Atlantic continental shelf the strongest shaking was felt in the central part of that area and, especially, in the cities of Punta del Este and Maldonado. Motion of hanging lamps and furniture were perceived, some bells rang and there were also reports of swings in the walls and falling objects from the shelves. The Seismological Observatory of the University of Brasilia assigned to it a regional magnitude of 3.9 with the epicenter located at $-36.55^{\circ} \mathrm{S},-53.50^{\circ} \mathrm{W}, 10 \mathrm{~km}$, according to the records obtained by the seismographic network installed in the area of the Itaipú dam (Brazil). 
Concerning the occurrence of continental earthquakes in Uruguay and near the Santa Lucia Basin (north of Montevideo), Sánchez-Bettucci et al. (2018a) reports the following low intensity and shallow earthquakes with an increasing number of reports over the last years thanks to the improvement of local seismological networks since 2015 .

A) On January $10^{\text {th }}, 1990$ at $22: 30$ hours, an earthquake with the epicenter near the town of La Paloma occurred (Department of Durazno, with coordinates $32^{\circ} 41^{\prime} \mathrm{S}$ and $55^{\circ} 35^{\prime} \mathrm{W}$ and a magnitude of III on the Modified Mercalli Scale). Local reports indicate that "initially a strong noise was felt (for some, similar to a thunder) accompanied immediately by vibrations of the floor, trepidation of glass, movement of hanging objects, furniture and falling objects from shelves, as well as some effects could be noted in various constructions". The origin of this phenomenon is uncertain although it has been attributed to tectonic readjustments in the area of the nearby Rincón del Bonete Dam on the Rio Negro (Negro River, Figure 1).

B) On March $23^{\text {rd }}, 2016$ at 23:26 local time an earthquake with epicenter in Puntas de Sayago (near Montevideo) occurred, but it was not possible to calculate neither the magnitude of the event nor its depth. Based on the data collected, it is suggested that it was not a single event. The first one would have happened at 23:10, the next one at 23:26 (higher intensity) at 01:30 (the next day) and according to reports from two interviews one last earthquake was felt at 03:00. However, it was not possible to identify such events in the seismogram due to high signal to noise ratio as they probably were of a very low magnitude. In some houses, things fell from the shelves (glasses, ornaments). Some reports indicate several cases of wall cracks.

C) On November $24^{\text {th }}, 2016$ an earthquake occurred that was felt by a large part of the population of the Department of Montevideo and South of the Department of Canelones. The epicenter was determined to the North of the locality of Las Piedras with coordinates $34.6925^{\circ} \mathrm{S}( \pm 4.2 \mathrm{~km})$, $56.2003^{\circ} \mathrm{W}( \pm 4.8 \mathrm{~km})$, depth: $12.3 \mathrm{~km}( \pm 6.0 \mathrm{~km})$ and a local magnitude of 3.4 (Castro et al., 2017). Using data collected via email and web surveys about the perception of the event by the population, a map of earthquake intensities was produced by Curbelo et al. (2017).

D) On September $4^{\text {th }}, 2017$ at 20:05 local time people reported some noise and tremors around Carmelo in the Colonia region (Sánchez-Bettucci et al., 2018a). This event was recorded by only one temporary accelerometer (station TCOPM) located in Minuano (Colonia Department), $85 \mathrm{~km}$ southeast of Carmelo (Figure 1). The epicentral distance and magnitude were calculated using data from this station. The first arrival of the $\mathrm{P}$ wave with positive polarity was recorded at 23:05:54 (UTC) and the S wave at 23:06:03 (UTC). The event was located $8 \mathrm{~km}$ away from Carmelo $\left(34.040^{\circ} \mathrm{S}, 58.210^{\circ} \mathrm{W}\right)$ and assigned a magnitude Mc 2.5 (Coda Magnitude). The perception of this event on the population is reflected on reports of vibrations or shaking of walls, floor and/or furniture. In general terms, the people who perceived this phenomenon were inside buildings or constructions.

\section{The November $30^{\text {th }}, 2018$ earthquake}

As it is well known by the citizens of Buenos Aires, a recent earthquake occurred on November $30^{\text {th }}, 2018$. Depending on the source of information, there are at least three different epicenters for this earthquake depending on which stations are being used in the calculation (Table 1). Different regional and global networks show the difficulties these networks face when locating an event in this region, indicating that the distribution of stations is not well suited for a proper analysis which is maybe induced by the lack of prominent earthquake activity what might appear as normal in a region considered to be of very low seismic risk.

Sabbione (2018a, 2018b) and Spinola (2018) reported that the seismological station of the Astronomical Observatory of the University of La Plata recorded the earthquake at 10:27:44 (local time), with the epicenter located at a distance of approximately $30 \mathrm{~km}$ west from the La Plata Station (Figure 3).

The results recently published by Venerdini et al. (2019) provided focal mechanism solution and a moment magnitude of 3.7 Mw using the P and S arrivals at 12 stations in Argentina, Uruguay and Brazil. 
Table 1. Different sources for the 30-11-2018, 13:27:38 UTC earthquake in Buenos Aires where it is possible to see the different epicentral locations for the same event. This is induced by the absence of nearby stations and the lack of a proper distribution of local and regional networks (https://www.emsccsem.org/Earthquake/earthquake.php?id =728920\#summary). Note that EMSC declared that used the INPRES location and have therefore the same parameters. *RAGA: Venerdini et al. (2019).

\begin{tabular}{ccccc}
\hline USGS & $3.2 \mathrm{mb} l \mathrm{lg}$ & $35.253^{\circ} \mathrm{S}$ & $58.419^{\circ} \mathrm{W}$ & Depth: $10 \mathrm{~km}$ \\
\hline INPRES & $3.8 \mathrm{mb}$ & $34.904^{\circ} \mathrm{S}$ & $58.483^{\circ} \mathrm{W}$ & Depth: $25 \mathrm{~km}$ \\
\hline EMSC & $3.8 \mathrm{mb}$ & $34.90^{\circ} \mathrm{S}$ & $58.48^{\circ} \mathrm{W}$ & Depth: $25 \mathrm{~km}$ \\
\hline USP & $3.1 \mathrm{~m}_{\mathrm{R}}$ & $34.44^{\circ} \mathrm{S}$ & $58.18^{\circ} \mathrm{W}$ & Depth: $0 \mathrm{~km}$ \\
\hline *RAGA & $3.7 \mathrm{Mw}$ & $34.90^{\circ} \mathrm{S}$ & $58.23^{\circ} \mathrm{W}$ & Depth: $19 \mathrm{~km}$ \\
\hline
\end{tabular}

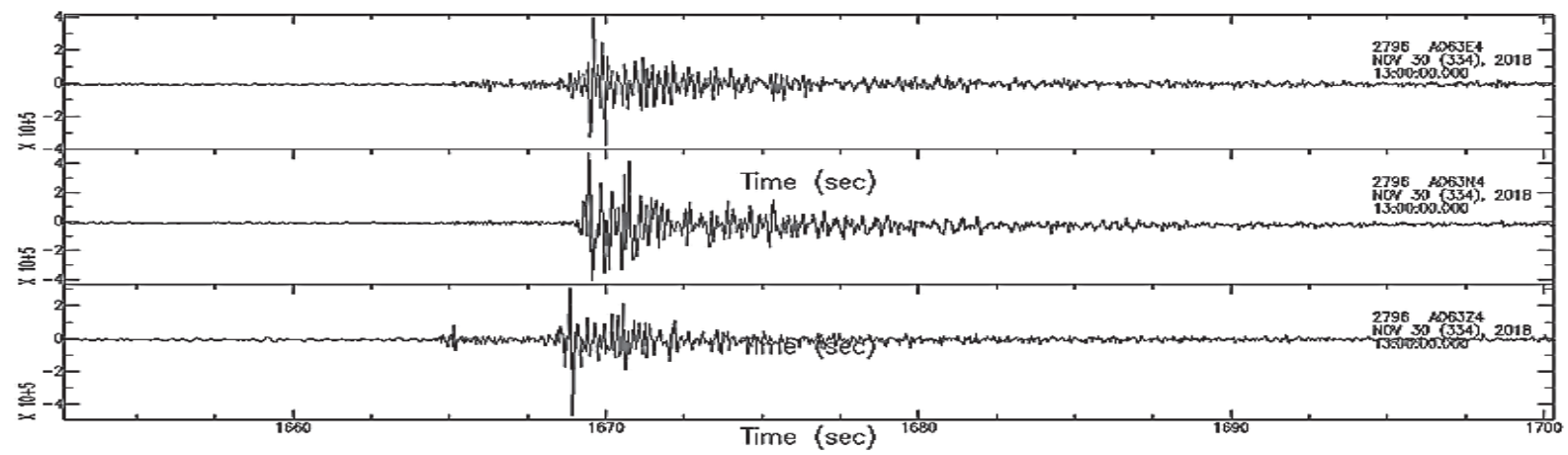

Figure 3. Digital records from the November $30^{\text {th }}, 2018$ earthquake showing the vertical and horizontal (North and East) components (taken from Sabbione, 2018a, 2018b; Spinola, 2018).

\section{Data}

We determined the November $30^{\text {th }}$ hypocenter using manual P- and S-wave arrival times (Bormann, 2012) at five stations: LPA, PSAL, TRQA, PLTB, and ITQB. Other two stations (CPSB and CNLB) part of the Brazilian Seismographic Network (RSBR) recorded the event, but were not used in this location due to its greater distance from the epicenter (676 and $938 \mathrm{~km}$ ) and low SNR levels (Table 2). The closest station is LPA, located at $33.6 \mathrm{~km}$ from the epicenter and the furthest considered station is located at $603 \mathrm{~km}$ (ITQB).

Data were manually picked considering the tree components records on filtered seismographs using a high pass filter with a corner frequency of $1.2 \mathrm{~Hz}$. Before filtering, data was de-trended and 1\% tapered at the edges to avoid border effects. The picking on the LPA station was made based on published data considering the seismogram plot presented in Figure 3 (Sabbione, 2018a, 2018b; Spinola, 2018). At other stations, the picking was performed using the SAC program on digital records.

Data was collected using IRIS and USP (Universidade de São Paulo) data center services. While most stations have $100 \mathrm{sps}$, TRQA has only $40 \mathrm{sps}$. Onset times for $\mathrm{P}$-wave and $\mathrm{S}$-wave are marked by the red lines on section (Figure 4). P-wave arrival is clear on most station until around $600 \mathrm{~km}$, further there is a matter of doubt. S-wave arrivals are also clear, mostly on the horizontal records not shown. Figure 4 shows a record section for all open digital available records for the earthquake.

\section{Location}

Final readings (Figure 4) used to locate the earthquake (Figure 1) are presented in Table 2, together with its attributed weights along with the last obtained residual. Hypocenter estimates used the modified velocity model proposed by Kwikto and Assumpção (1990) properly converted to be used with Hypo71 (converted from a spherical model to a flat model). This model shown in Figure 5 is the best fit for GT-5 regional events in Brazil and allows using of regional distance stations within stable South America. While this model is just a P-wave velocity model, it uses a constant $\mathrm{Vp}$ / $\mathrm{Vs}$ ratio of 1.74 , close to the theoretical value of 1.73 . The model has a crustal thickness of $40.12 \mathrm{~km}$, and a Pn velocity of $8.2 \mathrm{~km} / \mathrm{s}$. 
The final obtained hypocenter is located at $34.917^{\circ} \mathrm{S}$, $58.30^{\circ} \mathrm{W}$ with an estimated depth of $4.53 \mathrm{~km}$. Best fit origin time is origin 2018-11-30 13:27:38.60 UTC. Those parameters return an RMS of $0.25 \mathrm{~s}$ that corresponds to an average horizontal error of $2.3 \mathrm{~km}$ and a vertical error of $2.5 \mathrm{~km}$. This final location was made the Hypo71 program (Lee and Lahr, 1972).

Table 2. Readings and residuals computed to each of the considered stations while relocating the hypocenter. (LPA: La Plata, Argentina; PSAL: Uruguay; TRQA: Tornquist, Argentina; PLTB: Pelotas/PedrasAltas, Brazil; ITQB: Itaqui, Brazil; CPSB: Cacapava do Sul, Brazil; CNLB: Canela, Brazil).

\begin{tabular}{cccccccc}
\hline & & \multicolumn{2}{c}{ P-Wave } & \multicolumn{3}{c}{ S-Wave } \\
\hline \multirow{2}{*}{ Stations } & Date & Arrival Time & Weight & Res. & Arrival Time & Weight & Res. \\
\hline LPA & $2018 / 11 / 30$ & $13: 27: 44.41$ & 0.77 & 0.16 & $13: 27: 48.47$ & 0.80 & 0.03 \\
PSAL & $2018 / 11 / 30$ & $13: 28: 37.68$ & 1.54 & -0.33 & $13: 29: 22.00$ & 1.50 & 0.02 \\
TRQA & $2018 / 11 / 30$ & $13: 28: 44.11$ & 1.54 & 0.08 & $13: 29: 32.44$ & 1.50 & -0.01 \\
PLTB & $2018 / 11 / 30$ & $13: 28: 53.40$ & 0.77 & -0.38 & $13: 29: 49.29$ & 0.40 & -0.12 \\
ITQB & $2018 / 11 / 30$ & $13: 28: 59.85$ & 0.38 & 0.76 & $13: 29: 59.00$ & 0.80 & 0.35 \\
CPSB & $2018 / 11 / 30$ & $13: 29: 08.77$ & 0.00 & 0.85 & - & & - \\
CNLB & $2018 / 11 / 30$ & $13: 29: 39.69$ & 0.00 & 0.26 & - & & \\
UNSL & $2018 / 11 / 30$ & & & & & & \\
MRA & $2018 / 11 / 30$ & & & & & & \\
\hline
\end{tabular}

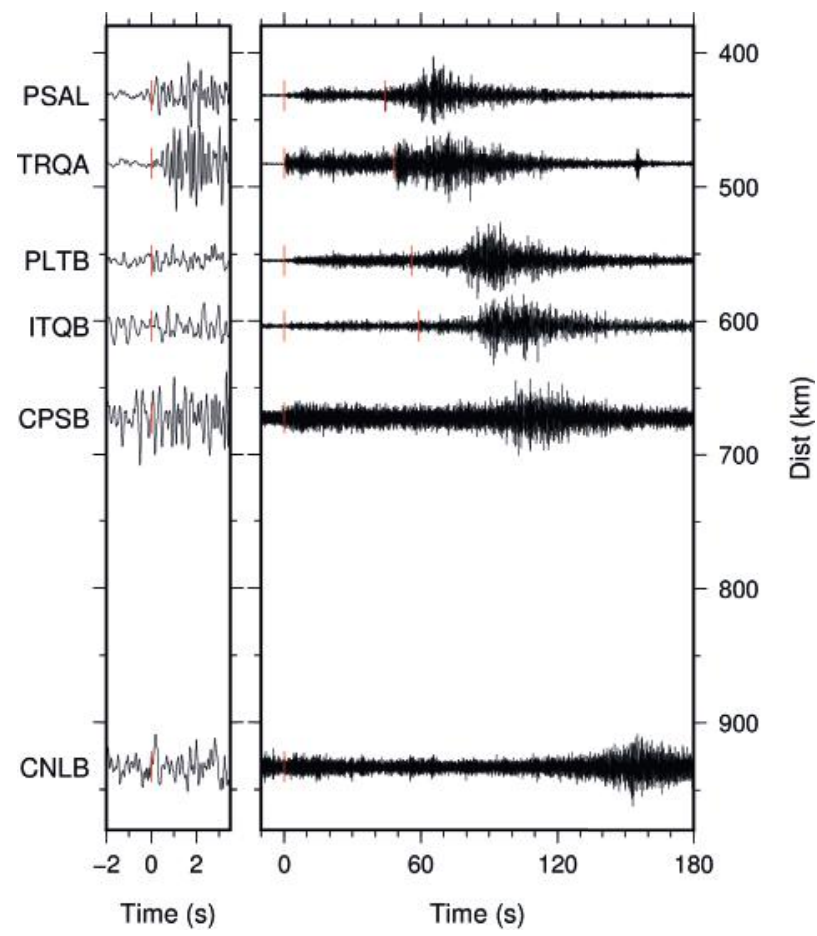

Figure 4. Seismic section for the regional events used in the location. Stations are sorted by distance from the epicenter and aligned according to $\mathrm{P}$-wave arrival times. Left zoom panel shows in detail the P-wave arrival window. Frequency is $\mathrm{f}>1.2 \mathrm{~Hz}$ for right panel and $1.2 \mathrm{~Hz}<\mathrm{f}<8.0 \mathrm{~Hz}$ for left panel. Stations on the left are (LPA: La Plata, Argentina; PSAL: Uruguay; TRQA: Tornquist, Argentina; PLTB: Pelotas/PedrasAltas, Brazil; ITQB: Itaqui, Brazil; CPSB: Cacapava do Sul, Brazil; CNLB: Canela, Brazil). 


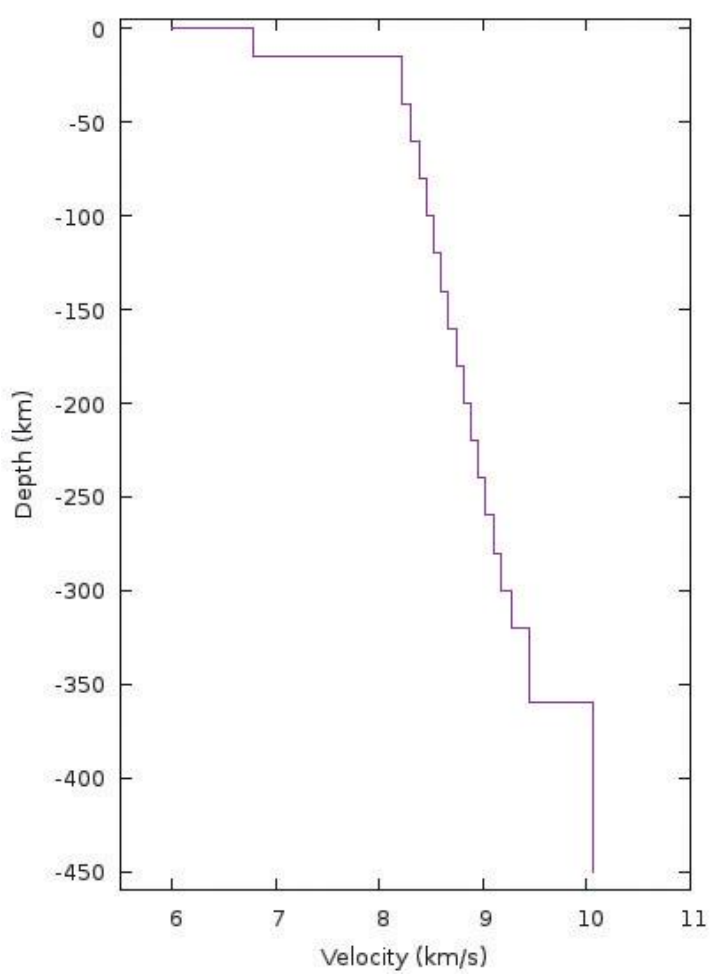

Figure 5. P-wave flat velocity model used by Hypo71 obtained from fitting travel time curves of GT-5 events in Brazil (unpublished derived work from Kwikto and Assumpção, 1990). Corresponding S-wave velocities can be estimated using a Vp/Vs of 1.74.

\section{The Rio de la Plata geological setting}

Although adequate seismic information and deep enough wells are not yet available on this riverine sector of the Rio de la Plata estuary in the Buenos Aires province, the Quilmes Trough was proposed by Rossello et al. (2011) as a western extension of the Santa Lucia Basin (Veroslavsky et al., 2004) that continues in the Argentine territory. This sedimentary infill exhibits a thickness of about $2000 \mathrm{~m}$ (Rossello et al., 2017, 2018) and would be essentially constituted by Jurassic to Tertiary sequences overlying basement that directly coalesce from the Santa Lucia Basin in the Salado Basin (Figure 6).

Gravimetric modeling from available geophysical data on the NE coast of Buenos Aires province, between Buenos Aires and Magdalena (Gianibelli and Ríos, 1989; Gianibelli et al., 1989) and the northern edges of the Salado Basin (Zambrano, 1974; Yrigoyen, 1975, 1993; Cabassi et al., 1996; Tavella and Wright, 1996) was performed (Rossello et al., 2011). These procedures allow the recognition of anomalies in the Rio de la Plata that suggest the presence of sedimentary volumes arranged on basal blocks with geophysical responses equivalent to those of the Santa Lucia Basin (Figure 7).
Gravimetric interpretation from sections modeled with the GMSYS ${ }^{\circledR}$ program in the Quilmes Trough suggests the presence of an extensional depocenter limited by high angle faults similar to the morphology of the Santa Lucia Basin (Figure 8). A map of Bouguer anomalies of the study area shows the relationship between the main gravimetric highs of the NEE and the San José and Montevideo mobile belts (Rapela et al., 2007; Oyhantçabal et al., 2018) and the continuity of these gravimetric features below the Rio de la Plata estuary and the margin of the Buenos Aires province (Figure 8). This map was created from Uruguay's terrestrial gravimetric stations (approximately 30,000), while for the rest of the study area the data was obtained from a Bouguer anomaly grid provided by the World Gravity Map 2012 (available on the website of Bureau Gravimétrique International).

The gravimetric interpretation suggests the presence of anomalies that coincide with the sedimentary volumes of the Meso-Cenozoic depocenters here studied. On the other hand, these gravimetric surveys have not recognized any structural feature arranged with NE orientation which can be attributed to the presence of del Plata High and/or Martín García. Likewise, the configuration of the Recalada Trough coincides 
with a gravimetric low, probably associated with a Precambrian paleo-suture of the crystalline basement and the presence of a thicker sedimentary cover. The Magdalena-Montevideo High (MMH) is recognized from a gravimetric high corresponding to the positive block that separates the Santa Lucía Basin and the Recalada Trough and coincides with the Pando Belt (Figure 8).
From these surveys, it is possible to identify a sedimentary depocenter, under the Quaternary cover, which occupies some $20,000 \mathrm{~km}^{2}$ of both continental and fluvial Buenos Aires territory on the western shore of the Rio de la Plata estuary (Figure 9).

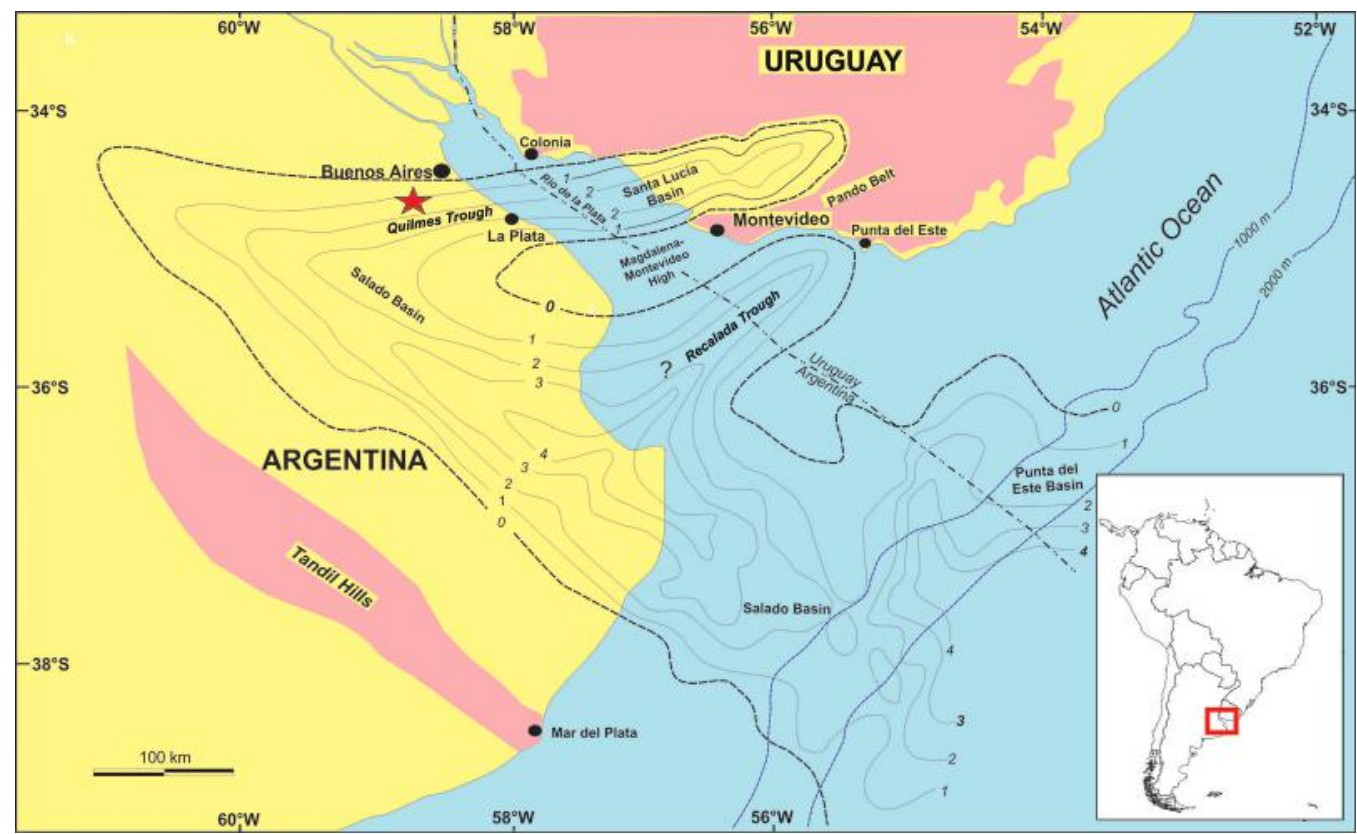

Figure 6. Location of the Quilmes and Recalada troughs and their relationships with the Salado and Santa Lucía basins with schematic isopach map of meso-cenozoic records (based on Rossello et al., 2011). The red star schematizes the position of the epicenters for $\mathrm{N} 30$.
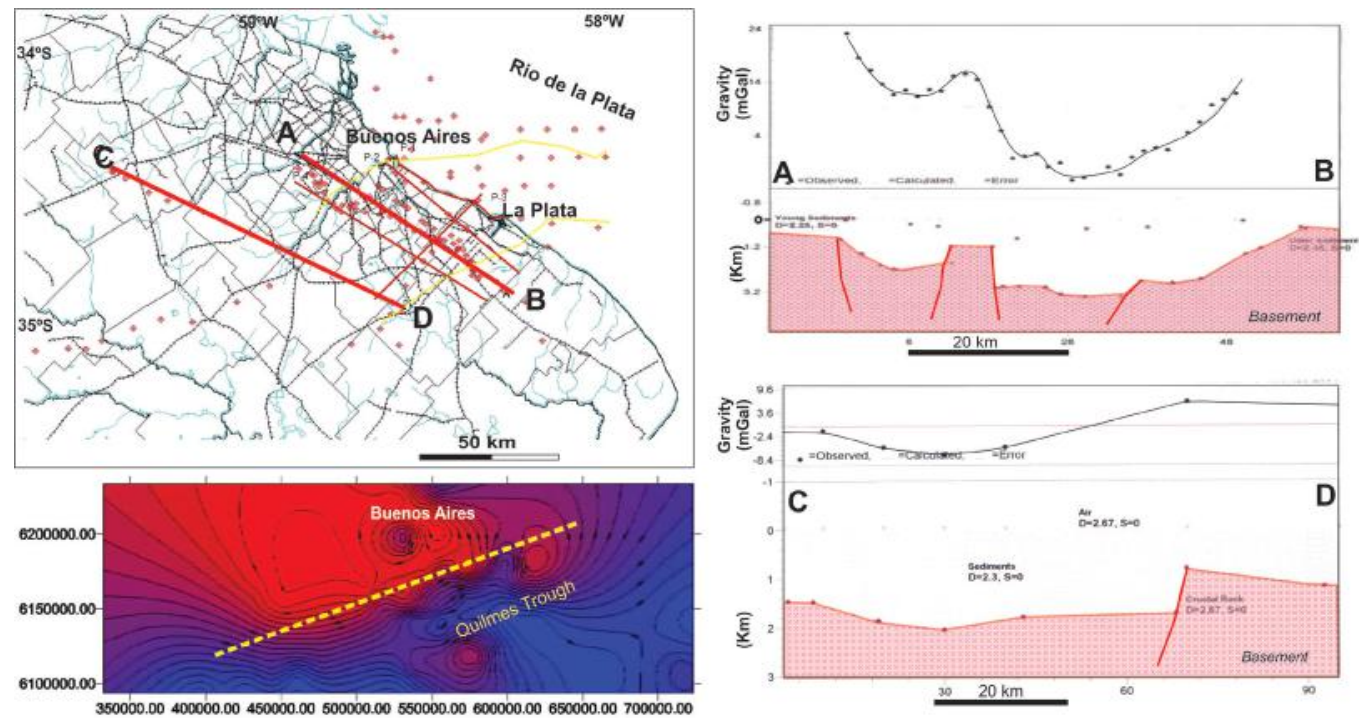

Figure 7. Location of gravimetric A-B and C-D sections on the southern margin of the Rio de la Plata in the Buenos Aires province modeled from GM-SYS (taken from Gianibelli and Ríos, 1989; Gianibelli et al.,1989; Rossello et al., 2011). Yellow lines represent the borders of the Quilmes Trough. 


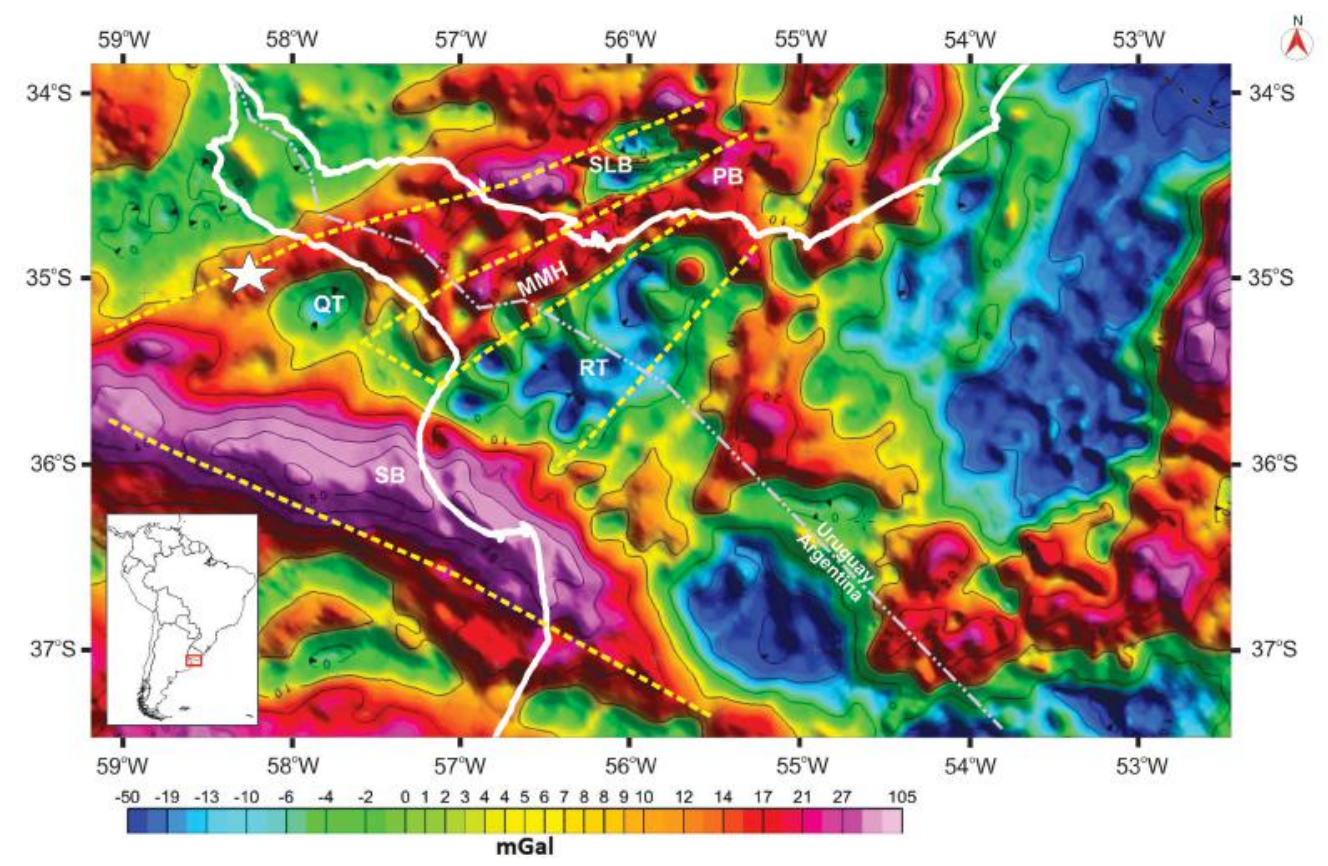

Figure 8. Map of the Rio de la Plata and adjacent areas from a Bouguer anomaly grid in the onshore and free air anomaly in the offshore (data from Bureau Gravimétrique International) and the $30^{\text {th }}$ November 2018 earthquake (white star). QT: Quilmes Trough, RT: Recalada Trough, MMH: Montevideo-Magdalena High; SLB: Santa Lucia Basin; PB: Pando Belt, and SB: Salado Basin. The gray dashed line indicates the position of the international border between Argentina and Uruguay. The yellow dashed lines indicate approximated meso-Cenozoic trough boundaries (taken from Rossello et al., 2018).

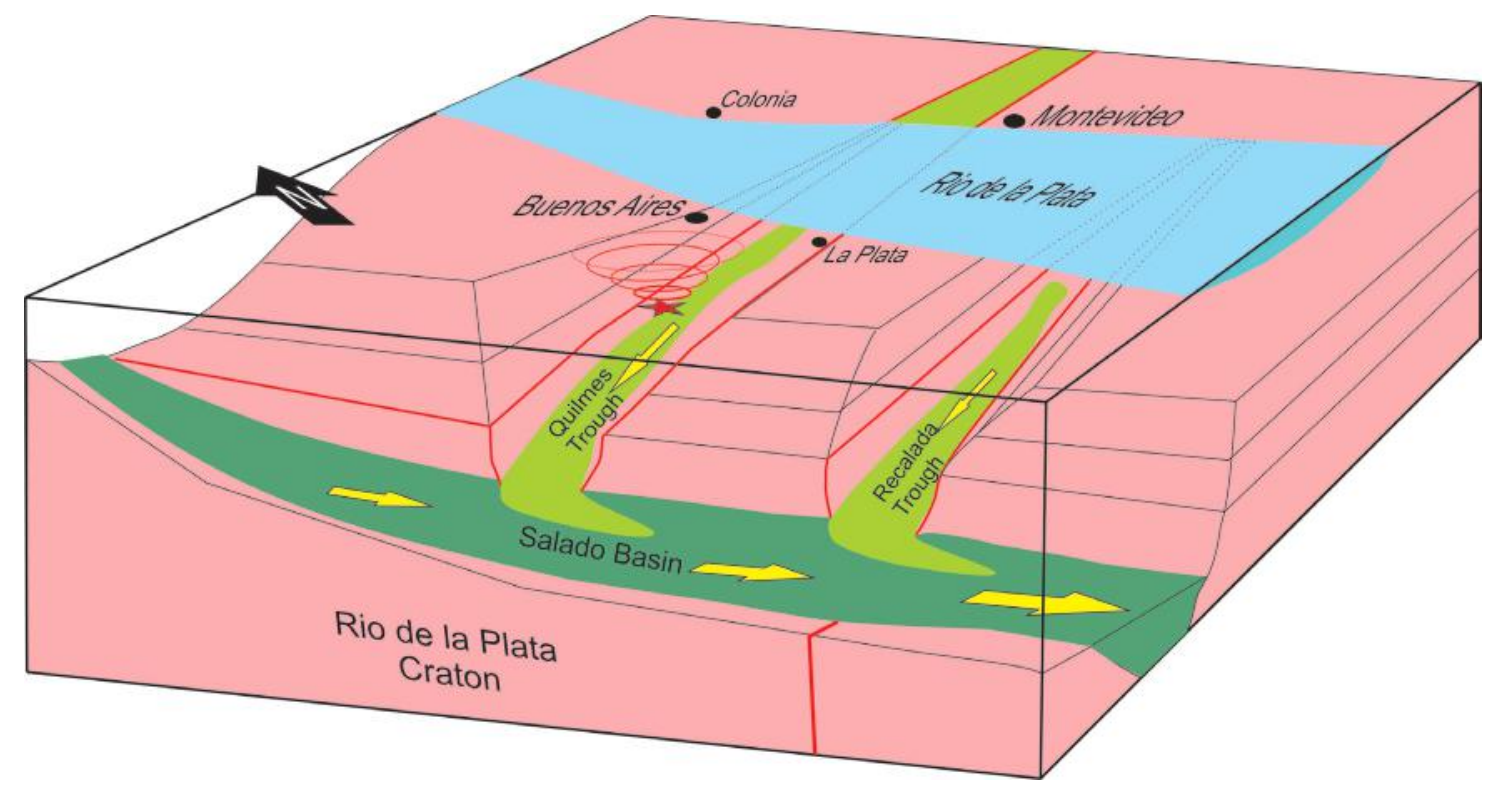

Figure 9. Three-dimensional cartoon (no scale) featuring the connection between the Santa Lucia Basin and the Quilmes and Recalada Troughs with the Salado Basin (modified from Rossello et al., 2011). Yellow arrow: sediment transport. 


\section{Discussion}

Regarding the series of 1888 earthquakes, the consequences of a similar seismic event would be today, without a doubt, of much greater impact than those experienced more than a century ago, given the urban development in the area, and the intense maritime traffic where the earthquake occurred. BenavídezSosa (1998) suggested that at least one these 1888 earthquakes might have been triggered by a landslide of large volumes of sediments that were accumulated by the constant drag of the Paraná and Uruguay rivers. This interpretation should be analyzed in more detail in the sedimentary record as it is necessary to investigate if there is certain repetition or periodicity of the phenomenon in the geological record, which is until now not available.

Moreover, the construction of a bridge between those cities with a length of approximately $45 \mathrm{~km}$ is currently planned, whose midpoint will be located in the vicinity of the location of the epicenter of that earthquake. Further investigation of earthquakes as well as the improvement of seismological studies in this area might be crucial to determine an eventual differential movement of blocks within the zone of tectonic instability in the Rio de la Plata region.

The apparent absence of earthquakes in the Rio de la Plata region (including Buenos Aires and Uruguay) might be in part related to the lack of seismological network capable of detecting lowmagnitude earthquakes. Low-frequency earthquakes do not produce wave frequencies high enough to be teleseismically measured (Yeats et al., 1997) and this is reflected in the absence of seismicity in wellestablished global networks. Crone et al. (1997) and Costa et al. (2001) suggested the recurrence period for intraplate settings might be too long (between 1 x 103 and $1 \times 105$ years).

The term intraplate earthquake refers to a variety of earthquakes that occur within the interior of a tectonic plate, this stands in contrast to the term interplate earthquake, which occurs at the boundary between of a tectonic plates. Intraplate earthquakes are relatively rare compared to the more familiar boundary-located interplate earthquakes (Kato, 2009). Therefore, large intraplate earthquakes can inflict heavy damage as such areas have structures and buildings lacking seismic retrofitting (Hough et al., 2003). The intraplate earthquakes located far away from the plates margins, can be of great magnitude and cause enormous material and human damages such as the ones occurred in 1812 and 1813 in New Madrid, Illinois, USA (Johnston and Schweig, 1996), Gujarat (India) in 2001 (Bodin and Horton, 2004), Botswana in 2017 (Gardonio et al., 2018), with moment magnitudes of $8.3 \mathrm{Mb}, 7.7 \mathrm{Mb}$ and $6.5 \mathrm{Mb}$, respectively.

Reliable seismological information is necessary to estimate and evaluate the seismic hazard of a region. In this case, the Rio de la Plata region in Argentina lacks of seismological information and is therefore problematic when estimating the characteristics and location of possible zones of seismic potential.

From the geophysical and geological evidence, the previous existence in the Rio de la Plata estuary of a first-order structural feature along the international border between Argentina and Uruguay associated to a NW-trending tectonic high, identified as the Martín García High (Urien et al., 1995; Urien and Zambrano, 1996), is unjustified. New surface and subsurface interpretations under the waters of the Rio de la Plata estuary can determine two ENE-SSW trending depocenters with Meso-Cenozoic sedimentary fillings that reach an average thickness of almost $2000 \mathrm{~m}$ (Rossello et al., 2011, 2017). These are identified as: i) the western extension of the Santa Lucía Basin, that in Argentine territory was named Quilmes Trough, and ii) the newly-named Recalada Trough, separated by the Magdalena-Montevideo High (Figure 8).

Based on correlations from the best-known adjacent areas of the Santa Lucia Basin, the sedimentary infill has been estimated to comprise considerable amounts of sandstone and conglomerates lying associated with faulted blocks of the crystalline basement (Veroslavsky et al., 2004). The presence of these tectosedimentary records are evidencing the bathymetry of the Rio de la Plata estuary and the sedimentary dynamics of the recent estuarine deposits. The idea of a co-genetic tectonic origin for both the Santa Lucia and Salado basins suggests an evolution from a triple junction where they developed interconnected extensional arms that had common Mesozoic tectosedimentary histories related to the early opening of the Atlantic Ocean.

The historic earthquakes reported in the Buenos Aires province suggest that the seismicity can be concentrated in previous crustal discontinuities and in reactivated faults associated with ancient active boundaries of the QT as it has been already proposed for other equivalent scenarios (Sykes, 1978; Johnston and Kanter, 1990; Mooney et al., 2012). 
The current sub-latitudinal location of the QT is furthermore, regionally coincident with the direction of convergence between the Andean-Pampean flat-slab subduction complex from the West and from the MidAtlantic Ocean ridge-push and drag by asthenospheric flows from the East (Pardo-Casas and Molnar, 1987; Cahill and Isacks, 1992; Brooks et al., 2003; Sperner et al., 2003; Cobbold et al., 2007; Costa et al., 2006; Guzmán et al., 2007; Assumpção et al., 2016; Brunetto et al., 2019; Heidbach et al., 2018). These references allow assuming the current maximum horizontal stress orientation for the Pampean region with an azimuth of $80^{\circ}$, which is slightly oblique with respect to the QT (Figure 10).

This spatial situation, where the principal stress vector is sub-parallel to preexisting tectonic discontinuities of the syn-sedimentary faulting of the QT, is possible according to Anderson's theory about the brittle response of the strain even with minor energy due to the facility of the media to trigger trans-tensional dextral reactivations in pre-existing mechanical discontinuities
(Ramsay and Huber, 1983; Price and Cosgrove, 1990). In consequence, this Neogene stress field located at less than $30^{\circ}$ in relation with the faulting that control the QT is available to produced tectonic reactivation with the subsequent generation of seismicity.

Until a few years ago it was always assumed that the seismic risk decreased in Argentina from west to east, becoming negligible in its eastern edge. This region is usually considered to be of very low earthquake risk due to the relatively sparse earthquake activity, but as we have seen, there have occurred some minor earthquakes in the past in this region that merit further investigation. Prevention measurements such as those adopted in the earthquake prone regions in the west would not be necessary but precautions should be taken to allow the structures to withstand horizontal accelerations in the order of $5 \times 10^{-2} \mathrm{~g}$, which is equivalent to making the structures and buildings resistant against earthquakes with a moment magnitude of 5 (Shearer, 2009).

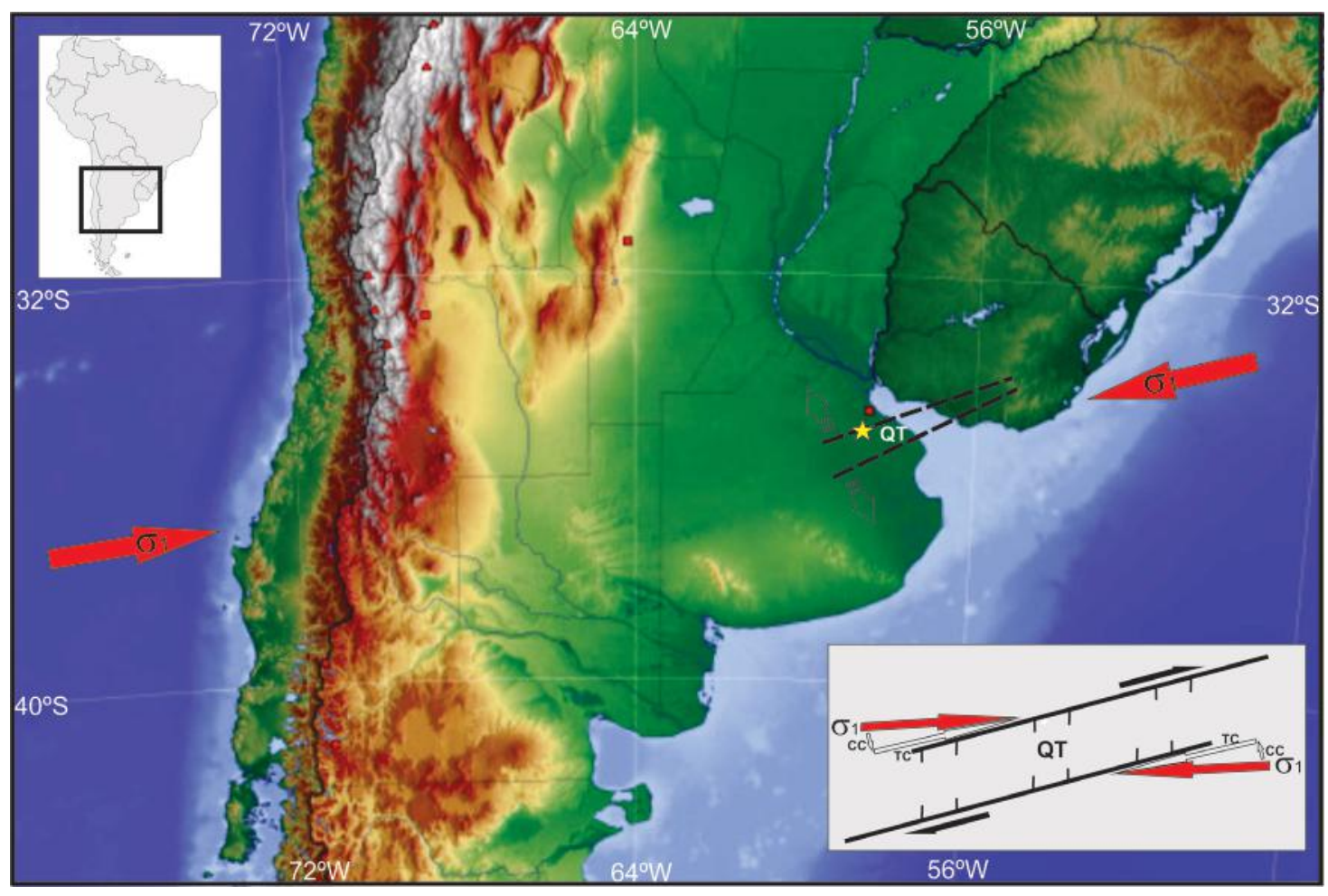

Figure 10. Schematic spatial relationship between the current Andean stress, the November $30^{\text {th }}$ earthquake (yellow star) and the QT. Red solid arrows show the generalized orientation of the maximum horizontal Andean stress, and black dashed lines indicate the approximate location of the QT. Open arrows on-shore indicate extension NW-SE. Inset: partitioning of the horizontal principal maximum stress vector $\left(\sigma_{1}\right)$ and the compressive orthogonal compound (CC) and transcurrent parallel compound (TC). 


\section{Conclusions}

The $3.8 \mathrm{mb}$ earthquake that occurred on November $30^{\text {th }} 2018$ near the city of Buenos Aires (with our obtained hypocenter located at $34.917^{\circ} \mathrm{S}, 58.300^{\circ} \mathrm{W}$ ) took place in a region where very little or no seismicity is recorded in the historical records. The earthquakes that happened in this region were always interpreted as tectonic events associated with the effects of the Rio de la Plata faulting but there is, up to date, no evidence to support this assumption from the geological and geophysical data.

The improvement of local and regional networks would allow us to identify earthquakes associated to tectonic activity of the Rio de la Plata faulting. The earthquake catalog from the local network in Uruguay, the Brazilian network south of Brazil and INPRES in western Argentina have no records of small earthquakes in the Rio de la Plata and the very few sparse earthquakes that exist do not appear to be related to a fault zone along the river and rather seem to be associated with a different orientation of stress release along a structure perpendicular to the strike of the Rio de la Plata River. Most of the seismicity recorded in this area, by local and regional instruments, seems to be located on the continental sides and not along the river.

For this reason, the existence of the recently described Quilmes Trough (Rossello et al., 2011) was proposed as a work hypothesis which could explain what stresses are acting to trigger the shallow estimated intraplate seismicity at a depth of $4.53 \mathrm{~km}$ where the epicenters are located coinciding with the proposed trace of the principal axis of the QT and it allows us to consider the existence of a modern right-lateral trans-tensional tectonic scenario.

This region of the Rio de la Plata and surrounding areas have always been known as having very low earthquake activity but based upon this new evidence we suggest that this could be interpreted as misleading information concerning the seismicity related to such faults is still unknown. In consequence, the existence of this shallow seismicity should be taken into account for developing and planning civil buildings and future extraction activities for fluids in the case of hydrocarbon or subterranean aquifers.

Considering all the points expressed above we suggest that it is imperative to improve the quality and the quantity of the observation points or earthquake observatories in this region and to investigate the origin and the fingerprint of these earthquakes in order to establish proper actions based on reliable hazard maps and risk analysis. Identifying possible active faults and the zones they might be affecting would be of great help to mitigate the effects of earthquakes on the infrastructure in a very populated area.

Last but not least, it is imperative to develop a reliable earthquake monitoring system in this region in order to improve the completeness of the earthquake catalogs that could provide invaluable data to delineate and define tectonic structures at depth. This data would also be used to produce focal mechanism solutions that will help to study the tectonic stress in this scant studied region from the seismological point of view.

\section{Acknowledgments}

We would like to express our gratitude to our Uruguayan colleague Dr. Gerardo Veroslavsky for its incentive and comments that helped us to considerably improve this work. We acknowledge the reviewers Maria Julia Orgeira and Paula Merea-Llanos for their comments and suggestions which helped to improve the manuscript.

\section{References}

Assumpção, M. (1998). Seismicity and stresses in the Brazilian passive margin. Bulletin of the Seismological Society of America, 88(1), 160-169.

Assumpção, M.; Dias, F.L.; Zevallos, I.; Naliboff, J.B. (2016). Intraplate stress field in South America from earthquake focal mechanisms. Journal of South American Earth Sciences, 71, 278-295. doi: 10.1016/j.jsames.2016.07.005

Benavídez-Sosa,A. (1998). Sismicidad y sismotectónica en Uruguay. Física de la Tierra, 10, 167-186.

Bodin, P.; Horton, S. (2004). Source parameters and tectonic implications of aftershocks of the $\mathrm{M}_{\mathrm{w}} 7.6$ Bhuj earthquake of 26 January 2001. Bulletin of the Seismological Society of America, 94(3), 818827. doi: $10.1785 / 0120030176$

Bormann, P. (2012). New Manual of Seismological Observatory Practice (NMSOP-2), IASPEI, GFZ German Research Centre for Geosciences, Potsdam. doi: 10.2312/GFZ.NMSOP-2 
Brooks, B.A.; Bevis, M.; Smalley Jr., R.; Kendrick, E.; Manceda, R.; Lauría, E.; Maturana, R.; Araujo, M. (2003). Crustal motion in the Southern Andes $\left(26^{\circ}-36^{\circ} \mathrm{S}\right)$ : Do the Andes behave like a microplate? Geochemistry, Geophysics, Geosystems, 4(10). doi: 10.1029/2003GC000505

Brunetto, E.; Sobrero, F.; Giménez, M.E. (2019). Quaternary deformation and stress field in the Rio de la Plata Craton (Southeastern South America). Journal of South American Earth Sciences, 91, 332-351. doi: 10.1016/j.jsames.2017.04.010

Cabassi, I.R.; Gianibelli, J.; Miranda, S.; Castiglione, B. (1996). Nuevos aspectos tectónicos del borde Norte de la Cuenca del Salado (Provincia de Buenos Aires, Argentina) a partir de resultados magnéticos. XIII Congreso Geológico Argentino - III Congreso de Exploración de Hidrocarburos. Buenos Aires, Argentina.

Cahill, T.A.; Isacks, B.L. (1992). Seismicity and shape of the subducted Nazca Plate. Journal of Geophysical Research: Solid Earth, 97(B12), 17503-17529. doi: 10.1029/92JB00493

Castro, H.; Curbelo, A.; Rodríguez, M.; Latorres, E.; Castro-Artola, O.; Núñez, P.; SánchezBettucci, L. (2017). Caracterización del evento sísmico UY24112016 - Las Piedras. XXVIII Reunión Cientifica de la Asociación Argentina de Geofísicos y Geodestas, Argentina.

Cobbold, P.R.; Rossello, E.A.; Roperch, P.; Arriagada, C.; Gómez, L.A.; Lima, C. (2007). Distribution, timing, and causes of Andean deformation across South America. Geological Society, London, Special Publications, 272, 321-343. doi: 10.1144/ GSL.SP.2007.272.01.17

Costa, C.; Audemard, F.; Bezerra, F.; Lavenu, A.; Machette, M.; Paris, G. (2006). An overview of the main Quaternary deformation of South America. Revista de la Asociación Geológica Argentina, 61(4), 461-479.

Costa, C.H.; Murillo, M.V.; Sagripanti, G.L.; Gardini, C.E. (2001). Quaternary intraplate deformation in the southeastern Sierras Pampeanas, Argentina. Journal of Seismology, 5(3), 399-409. doi: 10.1023/A:1011431827075
Crone, A.J.; Machette, M.N.; Bowman, J.R. (1997). Episodic nature of earthquake activity in stable continental regions revealed by palaeoseismicity studies of Australian and North American Quaternary faults. Australian Journal of Earth Sciences, 44(2), 203-214. doi: 10.1080/08120099708728304

Curbelo, A.; Rodríguez, M.; Castro, H.; Arduin, F.; Latorres, E.; Castro-Artola, O.; Sánchez-Bettucci, L. (2017). Percepción por parte de la población del evento sísmico UY24112016 - Las Piedras (Uruguay). XXVIII Reunión Cientifica de la Asociación Argentina de Geofísicos y Geodestas. La Plata, Argentina.

Gardonio, B.; Jolivet, R.; Calais, E.; Leclère, H. (2018). The April $2017 \mathrm{M}_{\mathrm{w}} 6.5$ Botswana earthquake: an intraplate event triggered by deep fluids. Geophysical Research Letters, 45(17), 88868896. doi: 10.1029/2018GL078297

Gianibelli, J.C.; Ríos, F.F. (1989). Aspectos geofísicos y tectónicos de la Cuenca del Salado. III Reunión Geotransectas América del Sur. Mar del Plata, Argentina.

Gianibelli, J.C.; Cabassi, I.R.; Suárez, E.A.; Barrío, L.; Weisz, S.; Petcoff, L.; Cingolani, C.A.; Sidoti, O.; Ríos, F.F. (1989). La anomalía del borde noreste de la Cuenca del Salado: transecta. III Reunión Geotransectas América del Sur. Mar del Plata, Argentina.

Guzmán, C.G.; Cristallini, E.O.; Bottesi, G.L. (2007). Contemporary stress orientations in the Andean retroarc between $34^{\circ} \mathrm{S}$ and $39^{\circ} \mathrm{S}$ from borehole breakout analysis. Tectonics, 26(3). doi: 10.1029/2006TC001958

Heidbach, O.; Rajabi, M.; Cui, X.; Fuchs, K.; Müller, B.; Reinecker, J.; Reiter, K.; Tingay, M.; Wenzel, F.; Xie, F.; Ziegler, M.O.; Zoback, M.L.; Zoback, M.D. (2018). The World Stress Map database release 2016: Crustal stress pattern across scales. Tectonophysics, 744, 484-498. doi: 10.1016/j. tecto.2018.07.007

Hough, S.E.; Seeber, L.; Armbruster, J.G. (2003). Intraplate triggered earthquakes: observations and interpretation. Bulletin of the Seismological Society of America, 93(5), 2212-2221. doi: $10.1785 / 0120020055$ 
INPRES (2019). Sismicidad en Argentina. Instituto Nacional de Prevención Sísmica. http://contenidos. inpres.gov.ar/sismologia/mapas

Jaschek, E. (1972). ¿Hay sismos en la Provincia de Buenos Aires?. Ciencia e Investigación, 28 (1-2), 26-29.

Jaschek, E.; Sabbione, N.; Sierra, P. (1982). Reubicación de sismos localizados en territorio argentino (1920-1963). Observatorio Astronómico de la Universidad Nacional de La Plata. Serie Geofísica, Tomo XI, $\mathrm{N}^{\circ} 1$.

Johnston, A.C.; Kanter, L.R. (1990). Earthquakes in stable continental crust. Scientific American, 262(3), 68-75.

Johnston, A.C.; Schweig, E.S. (1996). The Enigma of the New Madrid Earthquakes of 1811-1812. Annual Review of Earth and Planetary Sciences, 24, 339-384. doi: 10.1146/annurev.earth.24.1.339

Kato, N. (2009). A possible explanation for difference in stress drop between intraplate and interplate earthquakes. Geophysical Research Letters, 36(23). doi: 10.1029/2009GL040985

Kwikto, R.; Assumpção, M. (1990). Modelo de velocidades para o manto superior no Brasil e determinação de epicentros regionais. XXXVI Congresso Brasileiro de Geologia. Natal, Brasil.

Lee, W.H.K.; Lahr, J.C. (1972). HYPO71: a computer program for determining hypocenter, magnitude, and first motion pattern of local earthquakes. U.S. Geological Survey Report 72-224. doi: 10.3133/ ofr 72224

Mooney, W.D.; Ritsema, J.; Hwang, Y.K. (2012). Crustal seismicity and the earthquake catalog maximum moment magnitude $\left(\mathrm{M}_{\mathrm{cmax}}\right)$ in stable continental regions (SCRs): correlation with the seismic velocity of the lithosphere. Earth Planetary Science Letters, 357-358, 78-83. doi: 10.1016/j.epsl.2012.08.032

Nature. (1884). Brief note on Montevideo earthquake. Nature, 29, 437.

Navarro, C.A. (2012). Sismicidad Histórica de la República Argentina. INPRES. San Juan.
OGU. (2019). Historia de la sismicidad en Uruguay. Geophysical Observatory from Uruguay. Consulted in 15 October 2019: http://ogu.fcien. edu.uy/en_US/historia-de-la-sismicidad-enuruguay/

Oyhantçabal, P.; Cingolani, C.; Wemmer, K.; Siegesmund, S. (2018). The Rio de la Plata Craton of Argentina and Uruguay. In: S. Siegesmund; M.A.S. Basei; P. Oyhantçabal; S. Oriolo (eds.). Geology of Southwest Gondwana (pp. 89-105). Springer. doi: 10.1007/978-3-319-68920-3_4

Pardo-Casas, F.; Molnar, P. (1987). Relative motion of the Nazca (Farallon) and South American Plates since Late Cretaceous time. Tectonics, 6(3), 233248. doi: 10.1029/TC006i003p00233

Price, N.J.; Cosgrove, J.W. (1990). Analysis of geological structures. Cambridge, Cambridge University Press.

Ramsay, J.G.; Huber, M.I. (1983). The techniques of modern structural geology, 1: Strain analysis. London: Academic Press.

Rapela, C.W.; Pankhurst, R.J.; Casquet, C.; Fanning, C.M.; Baldo, E.G.; González-Casado, J.M.; Galindo, C.; Dahlquist, J. (2007). The Rio de la Plata craton and the assembly of SW Gondwana. Earth-Science Reviews, 83(1-2), 49-82. doi: 10.1016/j.earscirev.2007.03.004

Richter, C.F. (1958). Elementary seismology. London: W.H. Freeman and Company, Bailey Bros. and Swinfen Ltd.

Rossello, E.A.; Veroslavsky, G.; de Santa Ana, H. (2011). La Fosa de Quilmes: prolongación austral de la Cuenca Santa Lucia (Uruguay) en la Provincia de Buenos Aires (Argentina). XVIII Congreso Geológico Argentino. Neuquén, Argentina.

Rossello, E.A.; Veroslavsky, G.; de Santa Ana, H.; Rodríguez, P. (2017). Depocentros mesocenozoicos y rasgos tectónicos del basamento cristalino del Rio de la Plata (Argentina y Uruguay). Revista de la Asociación Geológica Argentina, 74(3), 283-294.

Rossello, E.A.; Veroslavsky, G.; de Santa Ana, H.; Rodríguez, P. (2018). Geology of the Rio de la Plata and the surrounding areas of Argentina and 
Uruguay related to the evolution of the Atlantic margin. Journal of South American Earth Sciences, 83, 147-164. doi: 10.1016/j.jsames.2017.12.010

Sabbione, N. (2018a). ¿Porqué ocurrió el temblor en la Provincia de Buenos Aires? Comunicación. Departamento de Sismología e Información Meteorológica, Facultad de Ciencias Astronómicas y Geofísicas, Universidad Nacional de La Plata. https://www.fcaglp.unlp.edu.ar/ articulo/2018/11/30/sismo_en_la_region

Sabbione, N. (2018b). Cómo fue el atípico sismo que sacudió el G20. Diario Noticias. Consultado el 15 de diciembre de 2018. https://noticias.perfil. com/2018/11/30/como-fue-el-atipico-sismo-quesacudio-el-g20/

Sánchez-Bettucci, L.; Castro, H.; Rodríguez, M.; Curbelo, A.; Arduin, F.; Núñez, P.; Latorres, E.; Castro-Artola, O. (2016). Informe de evento UY24112016-Las Piedras. Observatorio Geofísico del Uruguay, Facultad de Ciencias, Reporte, Montevideo.

Sánchez-Bettucci, L.; Rodríguez, M.; Castro, H.; Curbelo, A.; Latorres, E.; Lefebre, R. (2018a). Eventos sísmicos recientes en Uruguay (2016 2017). Revista Investigaciones, 1(1), 41-58.

Sánchez-Bettucci, L.; Suárez, N.; Campal, N.; Loureiro, J.; Curbelo, A.; Castro, H.; Rodríguez, M.; Latorres, E.; Castro-Artola, O.; Arduin, F.; Faraone, M.; Pascale, A.; Abelenda, E. (2018b). The new national geophysical and geodetic network (Uruguay). Seismological Research Letters, 89(2A), 458-466. doi: 10.1785/0220170109

Shearer, P.M. (2009). Introduction to seismology. Cambridge: Cambridge University Press (2nd Edition).

Sperner, B.; Müller, B.; Heidbach, O.; Delvaux, D.; Reinecker, J.; Fuchs, K. (2003). Tectonic stress in the Earth's crust: advances in the World Stress Map Project. Geological Society, London, Special Publication, 212, 101-116. doi: 10.1144/GSL. SP.2003.212.01.07

Spinola, E. (2018). Buenos Aires tembló: la sismicidad de la región en clave histórica y con el avance científico a mano. Argentina Investiga. http:// argentinainvestiga.edu.ar/noticia.php?\%20 titulo=buenos_aires_\%20temblo_la_sismicidad de_la_region_en_clave_historica_y_con_el_ avance_cientifico_a_mano\&id $=3421$

Stein, S.; Wysession, M. (2009). An introduction to seismology, earthquakes, and earth structure. New Jersey: John Wiley and Sons.

Sykes, L.R. (1978). Intraplate seismicity, reactivation of preexisting zones of weakness, alkaline magmatism, and other tectonism postdating continental fragmentation. Review of Geophysics 16(4), 621-688. doi: 10.1029/RG016i004p00621

Tavella, G.F.; Wright, C.G. (1996). Cuenca del Salado. XIII Congreso Geológico Argentino - III Congreso de Exploración de Hidrocarburos. Buenos Aires, Argentina.

Urien, C.M.; Zambrano, J.J. (1996). Estructura del margen continental. XIII Congreso Geológico Argentino - III Congreso de Exploración de Hidrocarburos. Buenos Aires, Argentina.

Urien, C.M.; Zambrano, J.J.; Yrigoyen, M.R. (1995). Petroleum basins of southern South America: an overview. In: A.J. Tankard; R. Suárez-Soruco; H.J. Welsink (eds.). Petroleum Basins of South America (pp. 63-77). Vol. 62. AAPG.

Venerdini, A.; López, L.; Orozco, P.; Sánchez, G.; Alvarado, P.; Perucca, L.; Galván, R. (2019). Parametrización sismológica del sismo del 30 de noviembre de 2018, Buenos Aires, Argentina. Revista de la Asociación Geológica Argentina, 76(3), 173-182.

Veroslavsky, G.; de Santa Ana, H.; Rossello, E.A. (2004). Depósitos del Jurásico y Cretácico Temprano de la región meridional de Uruguay: el lineamiento Santa Lucía-Aiguá-Merín. In: G. Veroslavsky; M. Ubilla; S. Martínez (eds.). Cuencas sedimentarias de Uruguay: geología, paleontología y recursos naturales: Mesozoico (pp. 117-142). 2da ed. Chapter VI. Montevideo: DIRAC.

Yeats, R.S.; Sieh, K.E.; Allen, C.R. (1997). The geology of earthquakes. Oxford University Press.

Yrigoyen, M.B. (1975). Geología del subsuelo y plataforma continental. VI Congreso Geológico Argentino. Bahía Blanca, Argentina. 
Yrigoyen, M.B. (1993). Morfología y geología de la ciudad de Buenos Aires. Evaluación e incidencia geotécnica. Actas de la Asociación Argentina de Geología Aplicada a la Ingeniería, 7, 7-38.

Zambrano, J.J. (1974). Cuencas sedimentarias en el subsuelo de la provincia de Buenos Aires y zonas adyacentes. Revista de la Asociación Geológica Argentina, 29(4), 443-469.

Eduardo Antonio Rossello

ORCID: 0000-0002-6466-9956

Benjamin Heit

ORCID: 0000-0001-7728-5137

Marcelo Bianchi

ORCID: 0000-0002-1650-4540

Received: 04 February 2020

Accepted: 14 April 2020 